Review

\title{
PERANAN UNSUR HARA MOLIBDENUM DALAM PENAMBATAN NITROGEN
}

\author{
Amar Ma'ruf
}

\section{INTISARI}

Ketersediaan unsur hara Molibdenum (Mo) pada tanah, khususnya tanah masam sangat terbatas, sementara keberadaannya sangat menentukan proses penambatan nitrogen secara biologis. Mo merupakan komponen meta-protein nitrogenase dan membantu proses penambatan nitrogen dan merupakan komponen yang sangat esensial diperlukan untuk metabolisme $\mathrm{N}$ bakteria. Untuk berfungsi dengan baik, enzim nitrogenase memerlukan unsur hara Mo. Defisiensi unsur hara Mo telah dilaporkan terjadi pada beberapa spesies tanaman. Gejala defisiensi Mo pada tanaman sangat bervariasi.Gejala yang sering timbul adalah klorosis atau daun berwarna kekuningkuningan. Makalah ini akan membahas tentang peranan unsur hara Mo dalam penambatan nitrogen.

\section{PENDAHULUAN}

Penambatan nitrogen dilakukan secara simbiosis antara bakteri tanah, rhizobium dengan tanaman leguminosa, sangat penting dalam fungsi ekosistem (Simms dan Taylor, 2002). Sejumlah besar kebutuhan nitrogen tanaman terutama leguminosa disumbang oleh penambatan melalui simbiosis antara bakteri yang memiliki enzim nitrogenase dengan tanaman leguminosa yang mampu mereduksi dinitrogen menjadi bentuk organik (Postgate, 1998 dalam Simms dan Taylor, 2002).

Hubungan antara bakteri dengan tanaman leguminosa pada umumnya bersifat mutualistik, tetapi strain rhizobia mempunyai efektivitas yang berbeda antara strain satu dengan yang lain (Burdon et al., 1999 dalam Simms dan Taylor, 2002). Simbiosis ini merupakan proses yang kompleks yang dipengaruhi oleh faktor biotik maupun faktor lingkungan. Pada tanah masam mungkin populasi rhizobium sedikit atau tidak ada sama sekali mengingat kebanyakan rhizobia tumbuh dan berkembang dengan baik pada $\mathrm{pH}$ netral. (Gardner et al. 1991). Tanah masam merupakanfaktor pembatas dalam proses fiksasi $\mathrm{N}_{2}$ secarasimbiosis, membatasi ketahanan hidup rhizobium dan menurunkan jumlah bintil akar (Zahran, 1999). 
Vitousek et al. (2002) mengemukakan bahwa untuk berfungsi dengan baik enzim nitrogenase memerlukan unsur hara Mo. Namun demikian keberadaan unsur hara Mo pada tanah tertentu pada umumnya sangat kurang. Sifat unsur hara ini sangat mobil di dalam tanah. Tulisan ini difokuskan pada peran salah satu unsurhara yaitu molibdenum yang merupakan komponen enzim nitrogenase dalam penambatan $\mathrm{N}_{2}$ secara biologik oleh asosiasi tanaman leguminosa dan bakteri rhizobia.

\section{PEMBAHASAN}

\section{Peran dan Ketersediaan Molibdenum}

Molibdenum merupakan salah satu unsur hara mikro yang diperlukan untuk pertumbuhan dan sangat jarang (Fortescue, 1992 dalam Mendel dan Hansch, 2002). Oksidasi Mo dalam tanah bervariasidari valensi II hingga bervalensi IV, tetapi dalam bentuk terlarut, hanya Mo valensi IV yang tersedia bagi tanaman.Defisiensi unsur hara Mo telah dilaporkan terjadi pada beberapa spesies tanaman (Gupta, 1997dalam Mendel dan Hansch, 2002).Kemungkinan gejala defisiensi Mo pada tanaman sangat bervariasi dan gejala yang sering timbul adalah klorosis atau daun berwarna kekuning-kuningan (Mendel dan Hansch,2002). Gejala yang timbul karena kekurangan Mo hampir menyerupai kekurangan N. Kekurangan Modapat menghambat pertumbuhan tanaman, daun menjadi pucat dan mati, pembentukan bunga terlambat, dan pembentukan benang sari berkurang (Roesmarkam dan Yuwono, 2002). Gejala defisiensi Mo umumnya terdapat pada tanah masam. Pada tanahmasam umumnya kadar Fe, Al, dan kadang-kadang Mnberlebihan (toksis). Oleh karena itu, gejala defisiensi Mo sering bergabung dengan adanya gejala keracunanFe ${ }^{3+}$ dan $\mathrm{Mn}^{2+}$.

Roesmarkam dan Yuwono (2002) melaporkan bahwa ketersediaan Mo dalam tanah dipengaruhi oleh adanya pengapuran, perubahan suasana reduksi oksidasi, mikroorganisme, dan harkat Mo tersedia. Ketersediaan Mo meningkat dengan meningkatnya $\mathrm{pH}$, sehingga pemberian kapur meningkatkan ketersediaan Mo (Gadner et al. 1991). Hakim et al. (1986) melaporkan bahwa pada $\mathrm{pH}$ rendah, hampir tidak ada molibdenum yang tersedia. Selanjutnya Roesmarkam dan Yuwono (2002) mengemukakan bahwa Mo yang larut dalam air sangat sedikit $(<0,1 \mathrm{ppm})$ dan kelarutannya dipengaruhi oleh $\mathrm{pH}$ tanah. Makin rendah $\mathrm{pH}$ tanah, makin rendah pula tingkat kelarutannya dan sebaliknya. Hal ini diduga karena makin rendah $\mathrm{pH}$, makin tinggi kelarutan $\mathrm{Fe}$ 
danAl dan kemudian, Fe ini mengikat Mo. Ikatan Fe-Motergolong kuat sehingga tidak tersedia untuk tanaman.Ion $\mathrm{MoO}^{4-}$ sebagai anion terikat sering menyelimuti lempung yang bermuatan negatif pada permukaan luarnya.

Gadneret al. (1991) mengemukakan bahwa molibdenum mungkin berasal dari pelapukan sejumlah mineral yang meliputi $\mathrm{MoS}_{2}$ (tereduksi), komplek oksida seperti $\mathrm{CaMoO}_{4}$ dan bentuk terhidrasi.Molibdenum diserap oleh akar tanaman dalam bentukanion divalen $\left(\mathrm{MoO}_{4}{ }^{2-}\right)$.

Fungsi molibdenum dalam tumbuhan yang paling dikenal baik adalah menjadi bagian dari enzim nitrat reduktase yang mereduksi ion nitrat menjadi ion nitrit (Salisbury dan Ross, 1995; Gadneret al.1991 ). Mo berperan sebagai katalitis dan hanya ada dalamsatu ataubeberapa senyawa (enzim) saja.Fungsi Mo dalamtanaman adalah mengaktifkan enzim nitrogenase, nitrat reduktase, dan xantine oksidase (Roesmarkam danYuwono, 2002).

Molibdenum merupakan komponen yang sangat esensial yang diperlukan untuk metabolisme $\mathrm{N}$ bacteria (Thielet al., 2002).Mo-nitrogenase memerlukan suatuko-faktor berupa iron-molybdenum (Newton, 1992dalam Thiel et al., 2002).Mendel dan Hansch(2002) mengemukakan bahwa elemen molybdenum esensial hampir pada semua organisme dan terdapatpada lebih dari 40 enzim katalisator berbagai reaksiredox. Empat jenis ditemukan pada tanaman yaitu (1)Nitrate reductase katalisator yang merupakan kunciawal pada asimilasi nitrogen anorganik; (2) aldehydeoxidase yang berperan sebagai katalisator dalam prosesakhir biosintesis fitohormon abscisic acid; (3) xanthinedehydrogenase yang terlibat dalam katabolisme purindan reaksi stress, dan (4) sulphite oxidase yangkemungkinan terlibat dalam detoksifikasi ekses sulfit.

Tanah masam yang disebabkan antara lain oleh meningkatnya hujan asam dan pemupukan $\mathrm{N}$ secaraterus menerus, menghambat produksi tanamanleguminosa (Graham dan Vance, 2002). Konsentrasi ion $\mathrm{H}$ per se, keracunan $\mathrm{Al}$ dan $\mathrm{Mn}$, dan defisiensi $\mathrm{P}, \mathrm{Mo}$ atau Ca berkontribusi terhadap penurunan produksi leguminosa (Graham, 1992).Nodulasi dan ketahananhidup rhizobia dalam tanah terutama dipengaruhi olehkondisi keasaman tanah (Graham dan VANCE, 2003).

Sifat unsur hara ini sangat mobil di dalam tanah.Jumlah Mo dalam tanah sangat sedikit yaitu berkisar antara 0,2 hingga $10 \mathrm{ppm}$ dan umumnya antara 0,5hingga 3,5 ppm (Hakimet al. 1986). Jumlah ini relative lebih banyak pada tanah liat daripada tanah pasir dantanah organik. Menurut Roesmarkam dan Yuwono(2002) harkat Mo dalam tanah adalah sangat tinggi bila lebih 
besar dari 1,50 ppm; tinggi 1,10 - 1,50 ppm;sedang 0,51 - 1,00 ppm, rendah 0,11 - 0,50 ppm dansangat rendah bila lebih rendah dari $0,10 \mathrm{ppm}$.

\begin{tabular}{lll}
\hline Jenis Tanah & Kandungan Mo (ppm) & Katagori \\
\hline Marsh & $0,17-1,4$ & Rendah - Tinggi \\
Podsolik abu Coklat & $0,1-0,5$ & Rendah \\
Gambut & $0,1-0,5$ & Rendah \\
Podsolik & $0,09-0,36$ & Sangat rendah - Rendah \\
\hline
\end{tabular}

Roesmarkam dan Yuwono (2002)

Tanah-tanah yang sering mengalami kekurangan Mo adalah (a) tanah pasir, (b) tanah yang mengalami podsolisasi, dan (c) tanah yang banyak mengandung sulfat. Tabel 1 memperlihatkan bahwa selain tanah podsolik coklat yang sangat rendah mengandung kadar Mo. Hubungan antara serapan Mo dengan ketersediaan sulfat adalah keterbalikan. Pada keadaan dimana menurunnya sulfat, maka ini berarti serapan Mo akan meningkat. Kadar Mo yang tinggi dalam tanaman akan mempengaruhi translokasi Fe dari akar ke bagian atas tanaman (Hakimet al., 1986).Salisbury dan Ross (1995), mengemukakan bahwa molibdenum banyak terdapat di tanah sebagai garam molibdat $\left(\mathrm{MoO}_{4}\right)$ dan juga sebagai $\mathrm{MoS}_{2}$ dan diserap dalam bentuk ion $\mathrm{MoO}^{4-}$.

Roesmarkam dan Yuwono (2002) mengemukakan bahwa Mo dapat membentuk ikatan kompleks dengan bahan organik tanah. Ikatan ini dikenal dengan khelat yang bermanfaat melindungi Mo dari fiksasi oleh lempung. Senyawa organik yang mengikat Mo tersebut adalah gugus ortho hidroksil yang meliputi alkohol, fenol, asam hidroksi dan asam organik mono basis. Mo dalam tanah juga dapat bergabung dengan senyawa yang mengandung $\mathrm{N}$, misalnya tirosin, tiramin, lisitin, dan protein.

Penambahan unsur hara Mo sebesar 0,45 kg ha-1dalam bentuk sodium molybdate secara nyata meningkatkan jumlah bintil akar dan produksi pigeonpea (Khurana dan Dudeja, 1981 dalam Waniet al.,1995), sedangkan penambahan $1 \mathrm{~kg}$ cobalt chloride,1 $\mathrm{kg}$ sodium molybdate dan $25 \mathrm{~kg} \mathrm{ZnSO}_{4} \mathrm{ha}^{-1}$ meningkatkan produksi chickpea berturut-turut sebesar10,7 dan 4\% dibandingkan dengan kontrol (Wanietal. 1995). Penambahan unsur hara Mo dapat meningkatkan produksi sebesar 28\% pada tanaman Arachis hypogaea dengan kandungan $\mathrm{N}$ daun lebih tinggi (Quaggioet al. 2004). 
Molibdenum merupakan bagian dari enzim nitrogenase, yang esensial dalam proses penambatan nitrogen, sehingga defisiensi Molibdenum lebih sering ditemukan pada tanaman leguminosa (Bailey dan Laidlaw, 1999 dalam Quaggioet al., 2004).

Pemberian unsur hara Mo pada tanaman kembang telang berpengaruh nyata terhadap jumlah bintil akardan berat segar bintil akar. Rataan jumlah bintil akar tanaman kembang telang yang diberi unsur hara Molebih tinggi dan berbeda nyata dibandingkan tanpa Mo. Demikian juga halnya dengan berat segar bintil akar (Armiadi, 2007). Keadaan ini menunjukkan bahwa keberadaan Mo pada tanah bagi tanaman kembang telang sangat penting dalam membentuk bintil akar,meskipun disadari bahwa Mo bukan satu-satunya faktor yang berpengaruh terhadap pembentukan bintilakar. Terdapat interaksi yang nyata antara tarafpemberian Mo dengan perlakuan inokulasi terhadapjumlah bintil akar tanaman kembang telang.Ketersediaan Mo berhubungan erat dengan perkembangan bintil akar (Anderson, 1956 dalam Kaiseret al. 2005). Penambahan Mo melalui tanamanakan disalurkan ke membran sel bintil akar untukmembentuk enzim nitrogenase, namun hingga saat inibelum ada informasi mengenai mekanisme yangmengontrol transportasi Mo ke bintil akar (Kaiseretal., 2005).

Menggunakan Acetylin reduction assay (ARA),peran Mo sangat penting pada tanaman berumur 30hari, ditunjukkan dengan adanya kecenderungan polameningkatnya aktivitas enzim nitrogenase jika secarabertahap Mo ditambahkan (Armiadi, 2007).Keberhasilan pemberian Mo melalui daunditentukan pula oleh media tanam dan jenis tanaman(Armiadi, 2007). Pada tanaman kedelai, tarafpemberian Mo melalui daun berpengaruh nyataterhadap berat kering daun, berat segar bintil akar,berat kering bintil akar pada media tanam pasir, namuntidak berpengaruh bila kedelai ditaman pada mediatanah (Armiadi, 2007).

\section{Enzim Nitrogenase}

Enzim adalah katalisator reaksi-spesifik kimiapada sistem biologi. Sebagian besar reaksi sel-sel hidupakan berlangsung sangat lambat bila reaksi tersebuttidak dikatalisis oleh enzim. Untuk dapat berfungsidengan baik, enzim nitrogenase membutuhkan unsurhara Mo (Vitousek et al., 2002).Salisbury dan Ross(1995) mengemukakan bahwa nitrogenase terdiri daridua protein yang berlainan, sering disebut protein Fedan protein Fe-Mo. Protein Fe-Mo mempunyai 2 atommolibdenum dan 28 atom besi; protein Fe mengandung4 atom besi di kelompok $\mathrm{Fe}_{4} \mathrm{~S}_{4}$. Baik molybdenum maupun besi menjadi tereduksi dan kemudiandioksidasi saat nitrogenase menerima 
elektron dariferedoksin dan mengangkutnya ke $\mathrm{N}_{2}$ untukmembentuk $\mathrm{NH}_{3}$. Adenosine Triphosphate (ATP)adalah bentuk energi yang diperlukan dalam prosespenambatan $\mathrm{N}_{2}$. Protein Fe mengangkut elektron keprotein Fe-Mo, disertai dengan hidrolisis ATP menjadiAdenosine Diphosphate (ADP).Protein Fe-Mokemudian meneruskan pengangkutan elektron menujuN ${ }_{2}$ dan menuju proton untuk membuat dua $\mathrm{NH}_{3}$ dansatu $\mathrm{H}_{2}$ (Gambar 1).

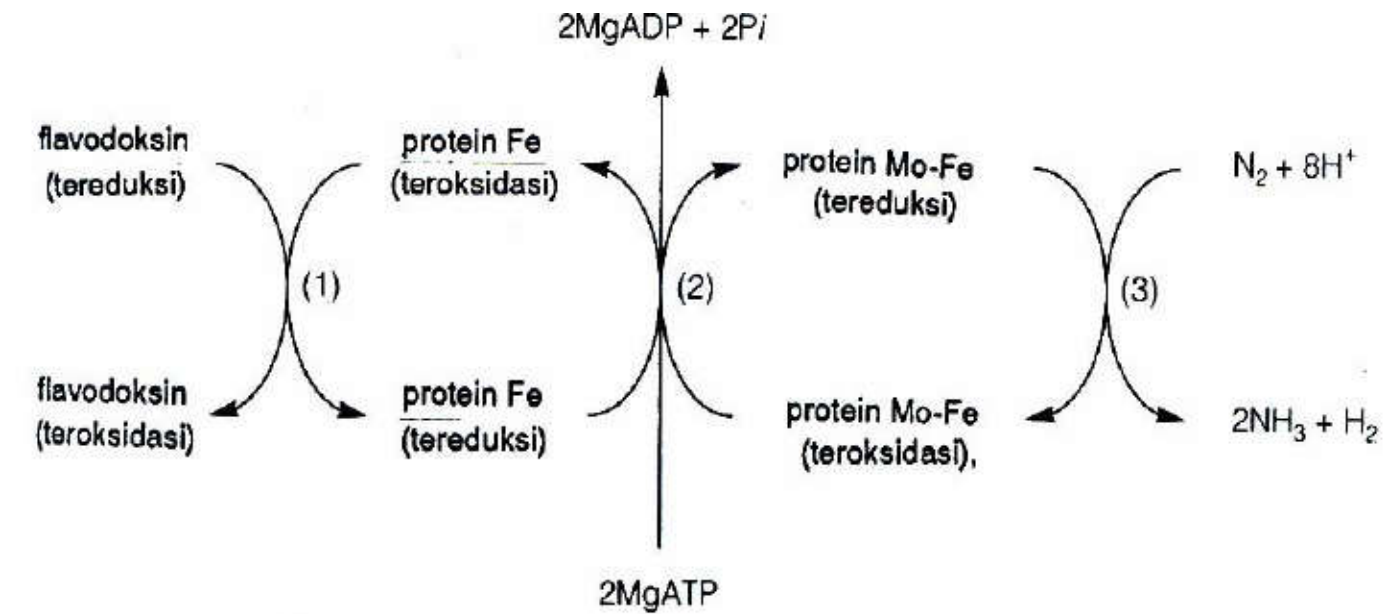

Gambar 1.pengangkutan elektron dari flavodoksin tereduksi ke $\mathrm{N}_{2}$ dan $\mathrm{H}^{+}$

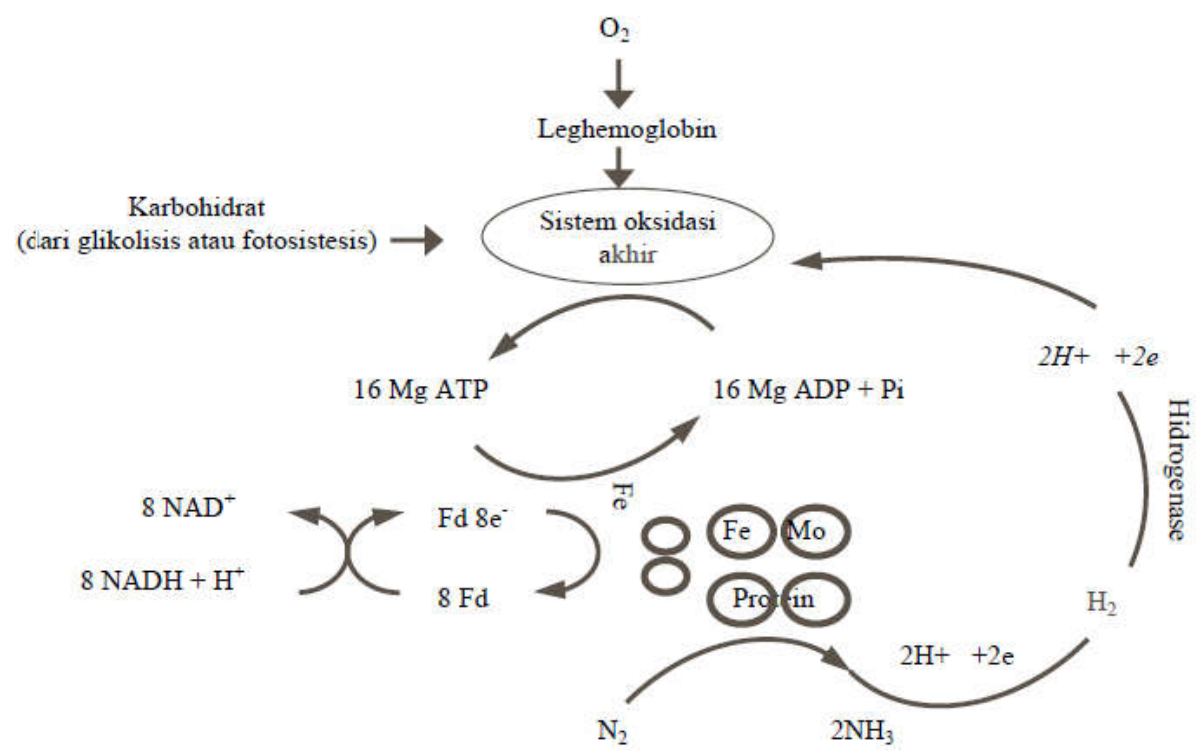

Gambar 2.Nitrogenase kompleks dan aktivitas yang berhubungan dengan penambatan nitrogen

Shilov (1992) mengemukakan bahwa nitrogenaseyang diisolasi dari berbagai bakteri penambat nitrogenterdiri dari dua protein yaitu protein Fe dan proteinMoFe.Protein Fe terdiri 
dari satu $\mathrm{Fe}_{4} \mathrm{~S}_{4}$ klaster,sedangkan protein MoFe terdiri dari dua FeMo kofaktordan empat $\mathrm{Fe}_{4} \mathrm{~S}_{4}$ klaster.Enzim nitrogenase sangat sensitif terhadapoksigen (Salisbury dan Ross, 1995), karena proteinFe dan protein Fe-Mo dari nitrogenase didenaturasisecara oksidatif oleh oksigen.Leghemoglobinmengendalikan sebagian ketersediaan oksigen di dalambakteroid, tetapi sifat anatomi yang rumit daribakteroid itu sendiri (seperti korteks dan endodermisyang mengelilingi berkas pembuluh dan sel yangmengandung bakteroid) nampak jauh lebih pentinguntuk mempertahankan tingkat oksigen yang rendah disekitar nitrogenase dengan bertindak sebagai pembatasdifusi ke udara di dalam tanah.

Moat dan Foster (1988) mengemukakan bahwanitrogenase terdiri dari dua protein yang sensitive terhadap oksigen, yaitu molibdenum iron proteinJumlah leghemoglobin dan luasnya jaringanbakteroid pada bintil akar berhubungan dengan jumlahN $\mathrm{N}_{2}$ yang ditambat oleh tanaman leguminosa (Moat danFoster, 1988).Reaksi katalisis oleh enzim nitrogenasemembutuhkan energi dalam bentuk ATP dan reduktan.Kebutuhan ATP dan reduktan dipenuhi dari hasilfotosintesis yang ditranslokasikan dari daun ke bintilakar.Pasangan enzim nitrogenase menghidrolisis ATPmenjadi ADP dengan memindahkan elektron darireduktan untuk mereduksi $\mathrm{N}_{2}$ menjadi $\mathrm{NH}_{3}$ (Yousafzaiet al., 1996). Persamaan keseluruhan dariproses penambatan $\mathrm{N}_{2}$ dapat ditulis sebagai berikut(Salisbury dan Ross, 1995; Moat dan Foster,1988):

$$
\mathrm{N}_{2}+8 \mathrm{e}+16 \mathrm{MgATP}+16 \mathrm{H}_{2} \mathrm{O} \rightarrow 2 \mathrm{NH}_{3}+\mathrm{H}_{2}+16 \mathrm{MgADP}+16 \mathrm{Pi}+8 \mathrm{H}^{+}
$$

Proses tersebut memerlukan sumber elektron danproton yang bersumber dari karbohidrat dan molekulATP. Juga diperlukan kompleks enzim yang disebutnitrogenase, yang mengkatalisis reduksi beberapasubstrat lain seperti asetilen (Salisbury dan Ross,1995). Reduksi asetilen menjadi etilen sering diukursebagai perkiraan laju penambatan nitrogen.Nitrogenase yang dihasilkan oleh Rhizobium dalam bintil akar akan mengkatalisis $\mathrm{N}_{2}$ menjadi $\mathrm{NH}_{3}$ dan $\mathrm{C}_{2} \mathrm{H}_{2}$ menjadi $\mathrm{C}_{2} \mathrm{H}_{4}$. Aktivitas nitrogenase biasanya diekspresikan dalam $\mu$ mol $\mathrm{C}_{2} \mathrm{H}_{4}$ (Sprent dan Sprent,1990).Efisiensi penambatan nitrogen dapat diukurdengan Acetylene $\left(\mathrm{C}_{2} \mathrm{H}_{2}\right)$ Reduction Assay (ARA) dannilai ARA dihitung dari banyaknya etilen (ethylene, $\mathrm{C}_{2} \mathrm{H}_{4}$ ) yang dihasilkan dari $\mathrm{C}_{2} \mathrm{H}_{2}$ (Hardyet al., 1968). Acetylene $\left(\mathrm{C}_{2} \mathrm{H}_{2}\right)$ Reduction Assay (ARA) terutama digunakan untuk mengetahui pengaruh perlakuanterhadap penambatan nitrogen dan bukan untukmemperkirakan jumlah nitrogen yang ditambat(Herridge dan Danso, 1995).

Kardinahlet al. (1999) mengemukakan bahwamolibdenum yang terdapat dalam enzim berperansangat penting dalam sistem biologi dan berfungsipenting dalam berbagai proses 
metabolisme. Nitratereductase katalisator merupakan langkah pertamadalam asimilasi nitrat dan merupakan kunci utamauntuk nutrisi tanaman (Mendel dan Hansch, 2002).Regulasi dari asimilasi nitrat merupakan bagian darisuatu kerjasama yang sangat kompleks untuk meresponberbagai signal dari lingkungan ataupun internaltanaman seperti nitrat, cahaya, $\mathrm{CO}_{2}$, fitohormon, danmetabolisme karbon dan nitrogen dengan tujuan untukmenghubungkan asimilasi nitrat dengan prosesmetabolisme lainnya. Pada tanaman kedelai, aktivitasnitrate reductase pada bakteroid mencapai 90\% daritotal nitrate reductase bintil akar (Lucinskiet al.,2002), sehingga terdapat nitrit yang bersifat toksiksebagai produk dari nitrate reductase, yang didugamenyebabkan penurunan aktivitas nitrogenase.

Konsentrasi oksigen bebas dalam bintil akarmerupakan faktor utama yang mempengaruhi aktivitasenzim nitrogenase (Layzell dan Hunt, 1990 dalamLucinskiet al., 2002). Ketersediaan oksigen di daerahbintil akar yang terinfeksi diatur oleh tanaman(Minchin, 1997 dalam Lucinskiet al., 2002),ketersediaan leghemoglobin dan dibatasi oleh resistensidifusi (Appelby, 1984).

Nitrat membatasi aktivitas nitrogenase pada bintil akar (Lucinskiet al., 2002). Pengaruh nitrat terhadap simbiosis antara leguminosa dan rhizobia antara lain adalah peranan ketersediaan nitrat selama proses infeksipada akar; hubungan antara ketersediaan nitrat dan aktivitas nitrogenase; dan pengaruh nitrat terhadap rasio antara massa basil akar dengan massa seluruh tanaman (Streeter,1988 dalam Lucinski et al., 2002).

\section{KESIMPULAN}

Molibdenum merupakan bagian dari enzimnitrogenase, yang esensial dalam proses penambatan nitrogen, sehingga defisiensi Molibdenum lebih sering ditemukan pada tanaman leguminosa. Ketersediaan Mo dalam tanah dipengaruhi oleh adanya kemasaman tanah,perubahan suasana reduksi oksidasi, mikroorganisme,dan harkat Mo tersedia. 


\section{DAFTAR PUSTAKA}

Appleby, C.A. 1984. Leghemoglobin And Rhizobium Respiration. Annu. Rev. Plant Physiol. 35 : $443-478$.

Armiadi.2007. Efektivitas Penambatan Nitrogen Udara Oleh Bakteri Rhizobium Dengan Penambahan Unsur Hara Molybdenum Pada Tanaman Leguminosa Herba. Disertasi. Program Pascasarjana Institut PertanianBogor.144 Hlm.

Gardner, F.P., R.B. Pearce And R.L. Mitchell. 1991. Fisiologi Tanaman Budidaya. Diterjemahkan oleh Susilo, H. Terjemahan Dari: Physiology Of Crop Plants. Universitas Indonesia Press, Jakarta. $425 \mathrm{Hlm}$.

Graham, P.H. 1992. Stress Tolerance In Rhizobium And Bradyrhizobium, And Nodulation Under Adverse Soil Conditions. Can. J. Microbiol. 38: 475 - 484.

Graham, P.H. And C.P. Vance. 2002. Nitrogen Fixation In Perspective: An Overview Of Research And Extention Needs. Field Crops Res. 65: 93 - 106.

Graham, P.H. And C.P. Vance. 2003. Legumes: Importance And Constraints To Greater Use. Plant Physiol. 131: 872- 877.

Ma'ruf, A. 2017. Agropastura Dan Pelestarian Kearifan Lokal Untuk Keberlanjutan Pertanian Di Asahan. Bernas

Ma'ruf, A. Sinaga, A. 2016. Pengaruh Pemanasan Global Terhadap Beberapa Tanaman C3 Di Indonesia. Bernas

Ma'ruf, A. Putra, E, T, S. Waluyo, S. 2016. Pengaruh Pyraclostrobin Terhadap Aktivitas Fisiologis, Produktivitas, Dan Kualitas Pucuk Teh Assamica (camellia Sinensis Var. Assamica (mast.) Kitamura) Pada Musim Kemarau. Universitas Gadjah Mada

Ma'ruf, A. Mardu, R. Andayani, N. 2014. Respon Bibit Mucuna bracteata Terhadap Intensitas Sinar Matahari. Institut Pertanian Stiper Yogyakarta

Ma'ruf, A. Zulia, C. Safruddin. 2017. Rice Estate Development As State Owned Enterprises (SOEs) To Self Supporting For Food. European Academic Research

Ma'ruf, A. 2016. Respon Beberapa Kultivar Tanaman Pangan Terhadap Salinitas. Bernas

Ma'ruf, A. Zulia, C. Safruddin. 2017. Legume Cover Crop di Perkebunan Kelapa Sawit. Forum Pertanian Asahan

Ma'ruf, A. (2017). AGROSILVOPASTURA SEBAGAI SISTEM PERTANIAN TERENCANA MENUJU PERTANIAN BERKELANJUTAN. Bernas, 13(1), 81-90.

Ma'ruf, Amar., Putra, E. T. S., \& Waluyo, S. EFFECT OF PYRACLOSTROBIN CONCENTRATION ON QUALITY SHOOTS OF ASSAMICA TEA.

Ma'ruf, A. Penggunaan Legume Cover Crop (LCC) di Perkebunan Kelapa Sawit.

Sinaga, A. Ma'ruf, A. 2016. Tanggapan Hasil Pertumbuhan Tanaman Jagung Akibat Pemberian Pupuk Urea, SP-36, dan KCl. Berna

Moat, A.G. And J.W. Foster. 1988. Microbial Physiology. 2nd Edition. John Wiley And Sons, Inc. America. $597 \mathrm{Hlm}$. 
Quaggio, J.A., P.B. Gallo And C. Owino-Geroh. 2004. Peanut Response To Lime And Molybdenum Application In Low Ph Soils. R. Bras. Ct. Solo 28: 659 - 664.

Roesmarkam, A. Dan N.W. Yuwono. 2002. Ilmu Kesuburan Tanah. Kanisius Yogyakarta. 224 $\mathrm{Hlm}$

Salisbury, F.B. Dan C.W. Ross. 1995. Fisiologi Tumbuhan.Jilid 2. Diterjemahkan Oleh: Lukman, D.R. Dan Sumaryono. Terjemahan Dari: Plant Physiology. Institut Teknologi Bandung, Bandung. $173 \mathrm{Hlm}$.

Shilov, A.E. 1992. Intermediate Complexes In Chemical And Biological Nitrogen Fixation. Pure \& Appl. Chem.54(10): 1409 - 1420.

Simms, E.L. And D. L. Taylor. 2002. Partner Choice InNitrogen-Fixation Mutualisms Of Legumes And Rhizobia. Integ. And Comp. Biol. 42: 369 - 380.

Sprent, J.L. And P. Sprent. 1990. Nitrogen Fixing Organisms: Pure And Applieds Aspect. Chapman And Hall, London. 282 P.

Thiel, T., B. Pratte And M. Zahalak. 2002. Transport Of Molybdate In The Cyanobacterium Anabaena Variabilis Atcc 29413. Arch. Microbiol. 179: 50 - 56.

Vitousek, P.M., K. Cassman, C. Cleveland, T. Crews, C.B. Field, N.B. Grimm, R.W. Howarth, R.Marino, L. Martinelli, E.B. Rastetter And J.I.Sprent. 2002. Towards An Ecological Understanding Of Biological Nitrogen Fixation. Biogeochem.57/58: 1- 45.

Wani, S.P., O.P. Rupela And K.K. Lee. 1995. Sustainable Agriculture In The Semi-Arid Tropics Through Biological Nitrogen Fixation In Grains Legumes. Plant And Soil174: 29 - 49.

Wiyanto, G. Ma'ruf, A. Puspaningrum, E, S. 2014. Panen Rupiah dari Ladang Jahe. Bhafana Publishing

Yousafzai, F.K., M. Buck And B.E. Smith. 1996. Isolation And Characterization Of Nitrogenase Mofe Protein From The Mutant Strain Phk 17 Of Klebsiellapneumonia In Which The Two Bridging Cysteine Residues Of The P-Cluster And Replaced By Noncoordinating Amino Acid Alanine. Biochem. J. 318:111 - 118.

Zahran, H.H. 1999. Rhizobium-Legume Symbiosis And Nitrogen Fixation Under Severe Conditions And In An Arid Climate. Microbiol. Mol. Biol. Rev. 63(4): 968 -989. 